\title{
KEEFEKTIFAN MODEL PEMBELAJARAN \\ STUDENT TEAM ACHIEVEMENT DIVISION TERHADAP \\ HASIL BELAJAR IPS SISWA KELAS V DI SDN KEDUNGBANTENG 01 \\ KABUPATEN TEGAL
}

\author{
Sofri Ulumudin \\ sofriulumudin7@gmail.com \\ Universitas PGRI Semarang
}

\begin{abstract}
ABSTRAK
Penelitian ini dilaksanakan dengan tujuan yaitu untuk mengetahui keefektifan model pembelajaran Student Team Achievement Division terhadap hasil belajar IPS materi perjuangan dalam mempersiapkan kemerdekaan Indonesia siswa kelas V semester II di SDN Kedungbanteng 01 Kabupaten Tegal. Hasil pengujian hipotesis pada hasil belajar siswa aspek kognitif menunjukkan bahwa $t_{\text {hitung }}=8,27$ dan $t_{\text {tabel }}=1,72$. Karena $t_{\text {hitung }}>t_{\text {tabel }}$ berarti penggunaan model pembelajaran Student Team Achievement Division dapat meningkatkan hasil belajar siswa aspek kognitif pada mata pelajaran IPS untuk kelas V SDN Kedungbanteng 01 Kabupaten Tegal. Rata-rata nilai pretest siswa adalah 45,96. Rata-rata nilai posttest 74,52. Sedangkan Kriteria Ketuntasan Minimal (KKM) adalah 65. Kesimpulanya bahwa model pembelajaran Student Team Achievement Division efektif terhadap hasil belajar siswa.
\end{abstract}

Kata kunci : keefektifan, model pembelajaran Student Team Achievement Division, hasil belajar

\section{PENDAHULUAN}

Pendidikan adalah kebutuhan yang paling mendasar pada masa sekarang ini sebagai sarana untuk pembentukan warga negara yang cerdas, cakap, kreatif, bertanggung jawab dan berkualitas. Seperti yang terkandung pada fungsi dan tujuan pendidikan nasional menurut UndangUndang Nomor 20 tahun 2003 tentang Sistem Pendidikan Nasional pasal 1 : Pendidikan adalah usaha sadar dan terencana untuk 
mewujudkan suasana belajar dan proses pembelajaran agar peserta didik secara aktif mengembangkan potensi dirinya untuk memiliki kekuatan akhlak mulia serta keterampilan yang diperlukan dirinya masyarakat, bangsa dan negara (Sisdiknas, 2004: 3).

Menurut Dimyati (2013:18) belajar merupakan proses internal yang kompleks. Yang terlibat dalam proses internal tersebut adalah seluruh mental yang meliputi ranah-ranah kognitif, efektif, dan psikomotor. Proses belajar yang mengaktualisasikan ranah-ranah tertuju pada bahan belajar tertentu.

Pada kegiatan pembelajaran disekolah, seorang guru memegang peranan yang sangat penting. Guru tidak hanya dituntut untuk memiliki kemampuan dalam pengalaman teoritis tapi juga harus memiliki daya tarik dalam pembelajaran agar siswa lebih tertarik untuk mengikuti pembelajaran.

Maka dari itu guru harus berupaya membuat inovasi-inovasi yang lebih menarik yang bisa membuat siswa lebih bersemangat untuk mengikuti pembelajaran. Untuk mencapai tujuan pembelajaran tersebut, situasi belajar dikelas haruslah di desain agar siswa dapat menikmati suasana belajar yang nyaman dan menyenangkan. Sumber yang dipakai haruslah sesuai dengan tujuan pembelajaran yang ingin dicapai.

Guru kelas V SDN Kedungbanteng 01 Kabupaten Tegal Ibu Khabibah, S.Pd mengatakan bahwa siswanya kurang bisa memahami pelajaran yang menyebabkan nilai IPS siswanya kurang memuaskan. Akibatnya akan berdampak pada hasil belajar yang kurang maksimal. Hal ini disebabkan dalam mengajar guru cenderung menggunakan metode yang monoton sehingga dalam proses pembelajaran tersebut siswa kurang aktif karena hanya mendengarkan dan mencatat saja. Dan suasana belajar seperti ini menimbulkan rasa bosan ketika 
menerima materi yang diberikan oleh guru.

Pembelajaran konvensional adalah pembelajaran yang biasa dilakukan oleh guru. Pada umumnya pembelajaran konvensional adalah pembelajaran yang lebih terpusat pada guru. Akibatnya terjadi praktik belajar pembelajaran yang kurang optimal karena guru membuat siswa pasif dalam kegiatan belajar. Siswa akan lebih banyak karena pembelajaran yang kurang menarik.

Menurut Syaiful metode ceramah adalah metode yang boleh dikatakan metode tradisional, karena sejak dulu metode ini telah dipergunakan sebagai alat komunikasi lisan antara guru dengan anak didik dalam proses belajar mengajar.

Pembelajaran pada metode ceramah peserta didik lebih banyak mendengarkan penjelasan guru di depan kelas dan melaksanakan tugas jika guru memberikan latihan soal-soal kepada peserta didik.
Oleh sebab itu seorang guru hendaknya menerapkan model dalam pembelajaran yang menarik dan membuat siswa lebih aktif. Untuk mengatasi permasalahan tersebut dibutuhkan suatu model pembelajaran yang menarik, dimana siswa lebih aktif dalam mengikuti pelajaran. Salah satu upaya untuk membuat siswa lebih aktif dan dapat meningkatkan hasil belajar siswa yaitu dengan menerapkan model pembelajaran STAD (Student Team Achievement Division).

Berdasarkan latar belakang diatas, maka dibuat perumusan masalahnya adalah "Apakah model pembelajaran Student Team Achievement Division efektif untuk meningkatkan hasil belajar IPS materi perjuangan dalam mempersiapkan kemerdekaan Indonesia siswa kelas $\mathrm{V}$ semester II SDN Kedungbanteng 01 Kabupaten Tegal ? 


\section{METODE}

Penelitian ini dilaksanakan di SDN Kedungbanteng 01 Kabupaten Tegal. Penelitian ini dilaksanakan pada tanggal 1-3 agustus 2018, dilakukan 3 kali pertemuan serta setiap pertemuan selama 70 menit

Variabel bebas dalam penelitian ini adalah model pembelajaran Student Team Achievemen Division. Variabel terikat dalam penelitian ini adalah hasl belajar hasil belajar IPS materi perjuangan dalam mempersiapkan kemerdekaan Indonesia siswa kelas $\mathrm{V}$ semester II SDN Kedungbanteng 01 Kabupaten Tegal. metode dalam peenelitian ini adalah metode kuantitatif. Desain penelitian yang digunakan adalah PreExperimental Designs Jenis penelitian yang digunakan adalah One Group Pretest-Posttest Design.

Populasi dalam penelitian ini adalah seluruh siswa kelas V SD N Kedungbanteng 01 Kabupaten Tegal, sedangkan Sampel dalam penelitian ini adalah siswa kelas $\mathrm{V} \quad \mathrm{SD} \quad \mathrm{N}$ Kedungbanteng 01 Kabupaten Tegal yang berjumlah 21 siswa. Peneliti menggunakan teknik sampling jenuh, yaitu bahwa semua anggota populasi digunakan sebagai sampel. Teknik pengumpulan data meliputi :

1. Tes

Menurut Arikunto (2010: 193) tes merupakan serentetan pertanyaan atau latihan serta alat lain yang digunakan untuk mengukur keterampilan, pengetahuan intelegensi, kemampuan atau bakat yang dimiliki oleh individu atau kelompok.Instrumen yang berupa tes ini dapat digunakan untuk mengukur kemampuan dasar dan pencapaian atau prestasi.

2. Observasi

Dalam penelitian ini observasi digunakan untuk mengetahui aktifitas selama proses pembelajaran. Hasil dari teknik observasi ini adalah berupa lembar observasi. 
3. Dokumentasi

Digunakan

untuk

memperoleh data nama-nama siswa serta nilai yang adan dijadikan sampel dalam penelitian dan dokumentasi kegiatan pembelajaran.

Instrumen pada penelitian ini berupa tes hasil belajar IPS. Analisis data dalam suatu penelitian merupakan bagian yang sangat penting, karena dengan adanya analisis data masalah dalam penelitian tersebut dapat diketahui jawabannya. Dalam langkah memilih pendekatan penelitian, telah dikemukakan beberapa desain eksperimen diantaranya telah disertai rumus atau analisis datanya. Untuk menganalisis, hasil ekspeimen dilakukan dengan uji normalitas awal, uji normalitas akhir, uji hipotesis.

\section{HASIL DAN PEMBAHASAN}

Dalam penelitian ini dilaksanakan pretest dan posttest untuk mengetahui dan mengukur kemampuan siswa setelah diberi perlakuan. Soal tes pretest dan posttest berupa soal pemecahan masalah namun dalam bentuk pilihan ganda yang berjumlah 20 soal. Soal-soal yang dikerjakan siswa digunakan untuk menilai kemampuan siswa dalam ranah kognitif, afektif, dan psikomotor. Berikut adalah hasil nilai soal pretest dan posttest.

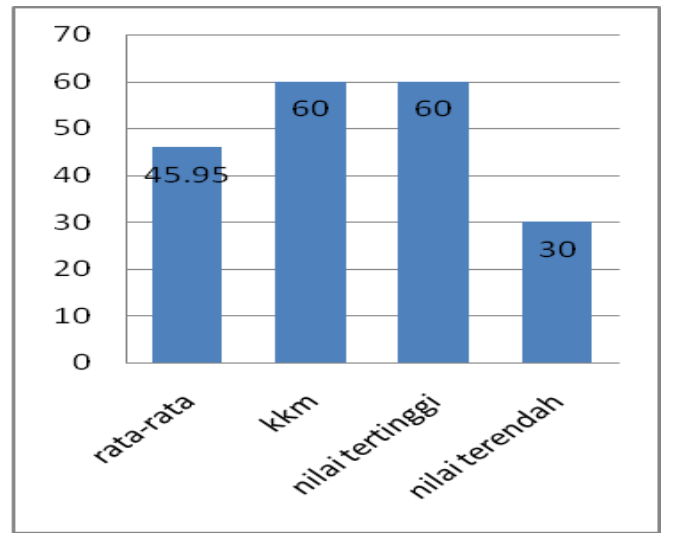

Gambar 1. Diagram Hasil Nilai Pretest

Berdasarkan gambar 1 ratarata nilai pretest adalah 45, 95. Sebanyak 18 siswa tidak tuntas dan hanya 3 siswa yang dinyatakan tuntas. Nilai terendah pada pretest adalah 30 , nilai tertingginya adalah 60 dan nilai KKM adalah 60. 


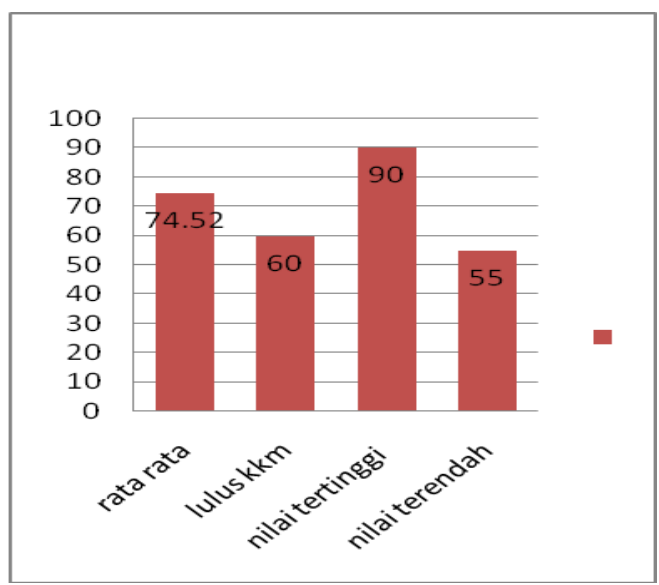

Gambar 2. Dagram Hasil Nilai Posttest

Berdasarkan gambar 2 ratarata nilai pretest adalah 74,52. Sebanyak 19 siswa tuntas dan hanya 2 siswa yang dinyatakan tidak tuntas. Nilai terendah pada posttest adalah 55 dan nilai tertingginya adalah 90 dan nilai KKM adalah 60.

Berdasarkan gambar 1 dan Gambar 2 dapat diketahui bahwa terdapat peningkatan rata-rata nilai IPS materi perjuangan dalam mempersiapkan kemerdekaan Indonesia sebelum dan sesudah diberi perlakuan. Dari penjelasan tersebut dapat disimpulkan bahwa terdapat perbedaan hasil belajar antara nilai sebelum diberi perlakuan dan nilai setelah diberi perlakuan model pembelajaran Student Team Achievement Division. Diagram tersebut juga menunjukan bahwa ratarata nilai posttest lebih tinggi dari ratarata nilai pretest, jadi dapat dikatakan bahwa ada peningkatan nilai sebelum dan sesudah diberi perlakuan yaitu menggunakan model pembelajaran Student Team Achievement Division.

Uji normalitas awal digunakan untuk mengetahui apakah nilai pretest berasal dari sampel yang berdistribusi normal atau tidak. Uji normalitas menggunakan rumus Lilifors dengan ketentuan bahwa kelompok berdistribusi normal jika memenuhi kriteria $L_{o}<L_{\text {tabel }}$ yang diukur pada taraf signifikasi $0,05 . \quad$ Hasil perhitungan uji normalitas awal dapat diukur pada Tabel 4.1

Tabel 1. Uji Normalitas Awal

\begin{tabular}{|c|c|c|c|}
\hline Nilai & $\boldsymbol{L}_{\boldsymbol{o}}$ & $\boldsymbol{L}_{\text {tabel }}$ & Ket \\
\hline Pretest & 0.1902 & 0.193 & Normal \\
\hline
\end{tabular}




\begin{abstract}
Berdasarkan Tabel 1 hasil perhitungan nilai Pretest dengan jumlah n sebanyak 21 siswa dan taraf signifikan 0,05 diperoleh $L_{o}=0,1902$, $\mathrm{L}_{\text {tabel }}=0,193$. karena $L_{o}<L_{\text {tabel }}$ maka Ho diterima. Artinya dapat disimpulkan bahwa sampel berdistribusi normal.

Uji normalitas akhir digunakan untuk mengetahui apakah nilai Posttest berasal dari sampel yang berdistribusi normal atau tidak. Uji normalitas menggunakan rumus Lilifors dengan ketentuan bahwa kelompok berdistribusi normal jika memenuhi kriteria $L_{o}<L_{\text {tabel }}$ yang diukur pada taraf signifikan 0,05.
\end{abstract}

Tabel 2. Uji Normalitas Akhir

\begin{tabular}{|c|c|c|c|}
\hline Nilai & $L_{o}$ & $L_{\text {tabel }}$ & Ket \\
\hline Posttest & 0.1130 & 0.193 & Normal \\
\hline
\end{tabular}

Berdasarkan pada tabel 4.2 hasil perhitungan nilai posttest dengan jumlah nilai n sebanyak 21 siswa dan taraf signifikan 0,05 diperoleh $L_{o}$
$=0,1130, L_{\text {tabel }}=0,193$, karena $L_{o}<$ $L_{\text {tabel }}$ yaitu < maka Ho diterima. Artinya dapat dikumpulkan bahwa sampel berdistribusi normal.

Berdasarkan hasil perhitungan uji $\mathrm{t}$ di peroleh hasil rata-ratanya adalah 45,95 untuk $\mathrm{x}_{1}$ dan 74,52 untuk $\mathrm{x}_{2}, \mathrm{Md}=29$, thítung nya adalah 8,2717 dan $t_{\text {tabel }}$ nya adalah 1,725 . Karena $t_{\text {hitung }}>t_{\text {tabel }} \quad$ yaitu $\quad 8,2717>1,725$ maka $\mathrm{H}_{\mathrm{o}}$ ditolak. Jadi, nilai rata-rata hasil belajar siswa dengan menggunakan model pembelajaran Student Team Achievement Division lebih efektif dari pada nilai rata-rata hasil belajar siswa yang tidak menggunakan model pembelajaran Student Team Achievement Division.

Setelah melakukan penelitian dengan menggunakan model Student Team Achievement Division terkumpul berbagai data seperti rata-rata nilai hasil belajar dan juga didapatkan data kriteria ketuntasan minimal. Pada ratarata nilai hasil belajar siswa sebelum diberi model Student Team 
Achievement Division adalah 45,96. Setelah diberi perlakuan dengan model Student Team Achievement Division nilai rata-rata hasil belajar siswa adalah 74,52 dengan persentase kenaikan sebesar $28,56 \%$. Hal tersebut diperkuat dengan hasil perhitungan uji $\mathrm{t}$ hasil belajar siswa diperoleh $\mathrm{t}_{\text {hitung }}$ $(8,2717)>t_{\text {tabel }}(1,725)$ maka uji t hasil belajar siswa ada perbedaan signifikan.

Dengan menerapkan model Student Team Achievement Division sebagai proses pembelajaran dapat meningkatkan hasil belajar siswa. Dari hasil analisis hasil belajar siswa menunjukkan peningkatan pada hasil belajar meningkat secara signifikan. Hal ini dikarenakan perhatian siswa dan antusiasme siswa pada saat proses pembelajaran baik. Hasil penelitian ini menunjukkan bahwa pembelajaran menggunakan model Student Team Achievement Division lebih baik dibandingkan dengan pembelajaran menggunakan model konvensional. Hal ini diperkuat dengan teori Piaget (1997) yang menunjukan bahwa siswa berusia sekolah dasar berpikir secara kongret. Jadi, dapat disampaikan bahwa model Student Team Achievement Division efektif terhadap hasil belajar siswa.

Hal ini diperkuat dengan penelitian yang relevan berkaitan dengan model pembelajaran Student Team Achievement Division adalah penelitian yang telah dilakukan oleh Dika Widyaningrum (2017) dengan judul "Pengaruh Model Pembelajaran Student Team Achievement Division Berbantu Media Audiovisual Terhadap Hasil Belajar IPA Siswa Kelas V SD Negeri Pedurungan Lor 01 Semarang”. Berdasarkan penelitian diketahui bahwa rata-rata pretest 60,5 dan ratarata posttest 80,4 dengan demikian dapat disimpulkan bahwa hasil belajar siswa setelah dilakukan dengan model pembelajaran Student Team Achievement Division mengalami peningkatan yang signifikan sebesar $54 \%$.

Tipe STAD merupakan salah satu tipe kooperatif yang menekankan pada 
adanya aktivitas dan interaksi diantara siswa untuk saling memotivasi dan saling membantu dalam menguasai materi pelajaran guna mencapai prestasi yang maksimal (Tukiran. 64 . 2014)

Setelah dilakukan pengujian diperoleh kesimpulan sebagai hasil penelitian menyatakan bahwa model Student Team Achievement Division efektif terhadap hasil belajar siswa pada materi perjuangan dalam mempersiapkan kemerdekaan Indonesia siswa kelas $\mathrm{V}$ SDN Kedungbanteng 01 Kabupaten Tegal.

\section{SIMPULAN}

Berdasarkan hasil penelitian yang dilakukan dapat disimpulkan bahwa model Student Team Achievement Division efektif terhadap hasil belajar siswa pada mata pelajaran IPS materi perjuangan dalam mempersiapkan kemerdekaan Indonesia siswa kelas $\mathrm{V}$ SDN Kedungbanteng 01 Kabupaten Tegal..
Hal tersebut diperkuat dengan: Ratarata nilai hasil belajar aspek kognitif pada nilai pretest rata-rata adalah 45,96 dan nilai rata-rata posttest adalah 74,52 persentase kenaikan hasil belajar adalah $28,56 \%$. Berdasarkan uji statistik diperoleh $\mathrm{t}_{\text {hitung }}(8,2717)>\mathrm{t}_{\text {tabel }}$ $(1,725)$ maka Ha diterima, artinya model Student Team Achievement Division efektif terhadap peningkatan hasil belajar siswa pada mata pelajaran IPS materi perjuangan dalam mempersiapkan kemerdekaan Indonesia siswa kelas $\mathrm{V}$ SDN Kedungbanteng 01 Kabupaten Tegal.

\section{SARAN}

Berdasarkan hasil penelitian yang telah dilakukan, peneliti dapat memberikan saran-saran sebagai berikut:

1. Guru dapat menggunakan model pembelajaran Student Team Achievement Division sebagai metode yang menarik dalam pembelajaran dan 
mampu meningkatkan hasil belajar siswa

2. Siswa diharapkan untuk bisa berpartisipasi secara aktif agar tujuan pembelajaran tercapai secara optimal.

3. Peneliti lain dapat melanjutkan penelitian dengan cakupan yang lebih luas.

\section{DAFTAR PUSTAKA}

Arikunto, S. 2010. Prosedur Penelitian. Jakarta: Rineka Cipta. 2013. Prosedur Penelitian. Jakarta: Rineka Cipta.

Cecep \& Bambang. 2013. Media Pembelajaran. Bogor: Ghalia Indonesia.

Dimyati. 2013. Belajar Dan Pembelajaran. Jakarta: PT Rineka Cipta.

Djamarah dan Aswan. 1996. Strategi Belajar Mengajar. Jakarta: PT Rineka Cipta.

Huda, M. 2015. Model-model Pengajaran Dan Pembelajaran. Yogyakarta: PustakaPelajar.
Ngalimun. 2016. Strategi Dan Model Pembelajaran. Yogyakarta: Aswaja Pressindo.

Purwanto. 2014. Evaluasi Hasil Belajar. Yogyakarta: PustakaPelajar.

Sisdiknas. 2003. Undang-Undang Republik Indonesia No.20 Tahun 2003. Semarang: Koordinator MPK-PKn IKIP PGRI Semarang.

Slameto. (2010). Belajar dan FaktorFaktor yang Mempengaruhinya. Jakarta: Rineka Cipta.

Sudjana. 2005. Strategi Pembelajaran. Bandung: Falah Production.

Sugiyono. 2010. Metode Penelitian Pendidikan (Pendekatan kuantitatif, kualitatif, dan $R \& D)$. Bandung: Alfabeta

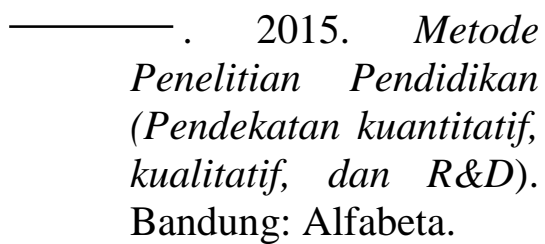

Susanto, A. 2013. Teori Belajar \& Pembelajaran di Sekolah Dasar. Jakarta: Kencana Prenada Media Group. 
Suyono dan Hariyanto. 2014. Belajar

Dan Pembelajaran. Bandung:

PT. Remaja Rosdakarya.

Tukiran dkk. 2014. Model-model Pembelajaran Inovativ dan Efektif. Bandung: Alfabeta.

Widyaningrum, D. 2017. "Pengaruh Model Pembelajaran STAD Berbantu Media Audiovisual Terhadap Hasil Belajar IPA Siswa Kelas V SD Negeri Pedurungan Lor 01 Semarang". Skripsi. Semarang. Universitas PGRI Semarang 